\title{
Heavy metal distribution in soil and plant in municipal solid waste compost amended plots
}

\author{
${ }^{1}$ F. Ayari; ${ }^{1}$ H. Hamdi; ${ }^{1}$ N. Jedidi; ${ }^{2} N$. Gharbi; ${ }^{2}$ R. Kossai \\ ${ }^{1}$ Water Research and Technology Center, Borj Cédria Technopark, P.O. Box 273 Soliman 8020, Tunisia \\ ${ }^{2}$ IPEIT, University of Tunis. Rue Jawaher Lel Nehru, Montfleury 1008, Tunis, Tunisia
}

Received 2 December 2009; $\quad$ revised 7 March 2010; accepted 16 May 2010; availab@ionline 1 June 2010

\begin{abstract}
A field study was carried out to evaluate long-term heavy metal accumulation in the top $20 \mathrm{~cm}$ of a Tunisian clayey loam soil amended for four consecutive years with municipal solid waste compost at three levels $(0,40$ and $80 \mathrm{t} / \mathrm{ha} / \mathrm{y})$. Heavy metals uptake and translocation within wheat plants grown on these soils were also investigated. Compared to untreated soils, compost-amended soils showed significant increases in the content of all measured metals: cadmium, chromium, copper, nickel, lead and zinc in the last three years, especially for plots amended with municipal solid waste compost at $80 \mathrm{t} / \mathrm{ha} / \mathrm{y}$. Wheat plants grown on compost-amended soils showed a general increase in metal uptake and translocation, especially for chromium and nickel. This heavy metal uptake was about three folds greater in plots amended at $80 \mathrm{t} / \mathrm{ha} / \mathrm{y}$ as compared to plots amended at $40 \mathrm{t} / \mathrm{ha} / \mathrm{y}$. At the end of the experimental period, the diluting effect resulting from enhanced growth rates of wheat plants due to successive compost applications resulted in lower concentrations in the plants (grain part) grown on treated plots. On the other hand, chromium and nickel were less mobile in the aerial part of wheat plants and were accumulated essentially in root tissues. Plant/soil transfer coefficients for compost-amended treatments were higher than threshold range reported in the literature, indicating that there was an important load/transfer of metal ions from soils to wheat plants.
\end{abstract}

Keywords: Compost; Heavy metals; Metal uptake; Wheat plants

\section{INTRODUCTION}

The concept of recycling waste nutrients and organic matter back to agricultural land is feasible and desirable. Land application represents a costeffective outlet for the producers of compostable wastes and a potential cheap source of organic matter and fertilizer elements for landowners (Petruzzelli et al., 1989; Chukwujindu, et al., 2006; Nouri et al., 2008).

Moreover, compost application to soil is used to maintain and improve soil structure (Paglia and Vittori-Antisari, 1993; Giusquiani et al., 1995; Lillenberg, et al., 2010) because its organic matter content can counteract the natural decline in intensively cultivated soils. It may even replace traditional farm manure whose availability in areas of intensive agriculture is often very poor. In addition to the potential beneficial nutrients, some waste materials may also contain non-essential elements,

凶*Corresponding Author Email: fethia_ayari@yahoo.fr Tel: +216 22558 118; Fax: +216 79325802 persistent organic compounds and microorganisms that may be harmful to plants (Kurihara, 1984; Mullin and Mitchell, 1994; Chukwuji et al., 2005). For instance, the presence of toxic heavy metals in municipal solid waste composts (MSWC) raises serious concerns about the adverse environmental impact as a result of excessive application to agricultural lands (Nicholson et al., 2003; Nouri et al., 2006; Ayari et al., 2008; Mahvi, 2008). Heavy metals originate mostly in non source-separated municipal solid wastes from a variety of sources: batteries, electronic appliances, newspapers, paint chips, foils, motor oils, and plastics that can all introduce metal contaminant into the compostable organic fraction (Hamdi et al., 2003). High and excessive accumulation of heavy metals in soil and other media may eventually contaminate both human and animal food chain (Williams et al., 1987; He et al., 1992; Chukwuji et al., 2005). For this reason, current European Community Regulations (1975 and 
1986) for land application of biowaste materials consider high content of heavy metals as a limiting factor for reuse purposes.

To correlate metal concentration in soil with plant uptake, a 4-year field study was undertaken: (a) to determine the accumulation of cadmium , chromium, copper, nickel, lead and zinc in the top $20 \mathrm{~cm}$ of an agricultural soil amended yearly with MSWC and (b) to determine the uptake of these metals and their distribution in wheat plants grown on this soil. To this end, a field-scale investigation was carried out from 1999 to 2002 at the agricultural experiment station of the Tunisia National Institute of Agronomy (INAT).

\section{MATERIALS AND METHODS}

Soil, MSWC and plant

The experiment station is located in northern Tunisia and belongs to the semi-arid superior bioclimatic stage with annual mean temperatures ranging between 15 and $29{ }^{\circ} \mathrm{C}$, and average annual rainfall of 400-450 mm (Benzarti et al., 2007). The soil is loamy-clay classified as Xerofluvent with some physico-chemical properties illustrated in Table 1.

MSWC was obtained from the municipal composting plant of Henchir Lihoudia landfill, near Tunis the capital. The urban compost was produced under aerobic conditions by slow fermentation for about five months. MSWC maturity was monitored

Table 1: Soil physico-chemical characteristics in different soil depths

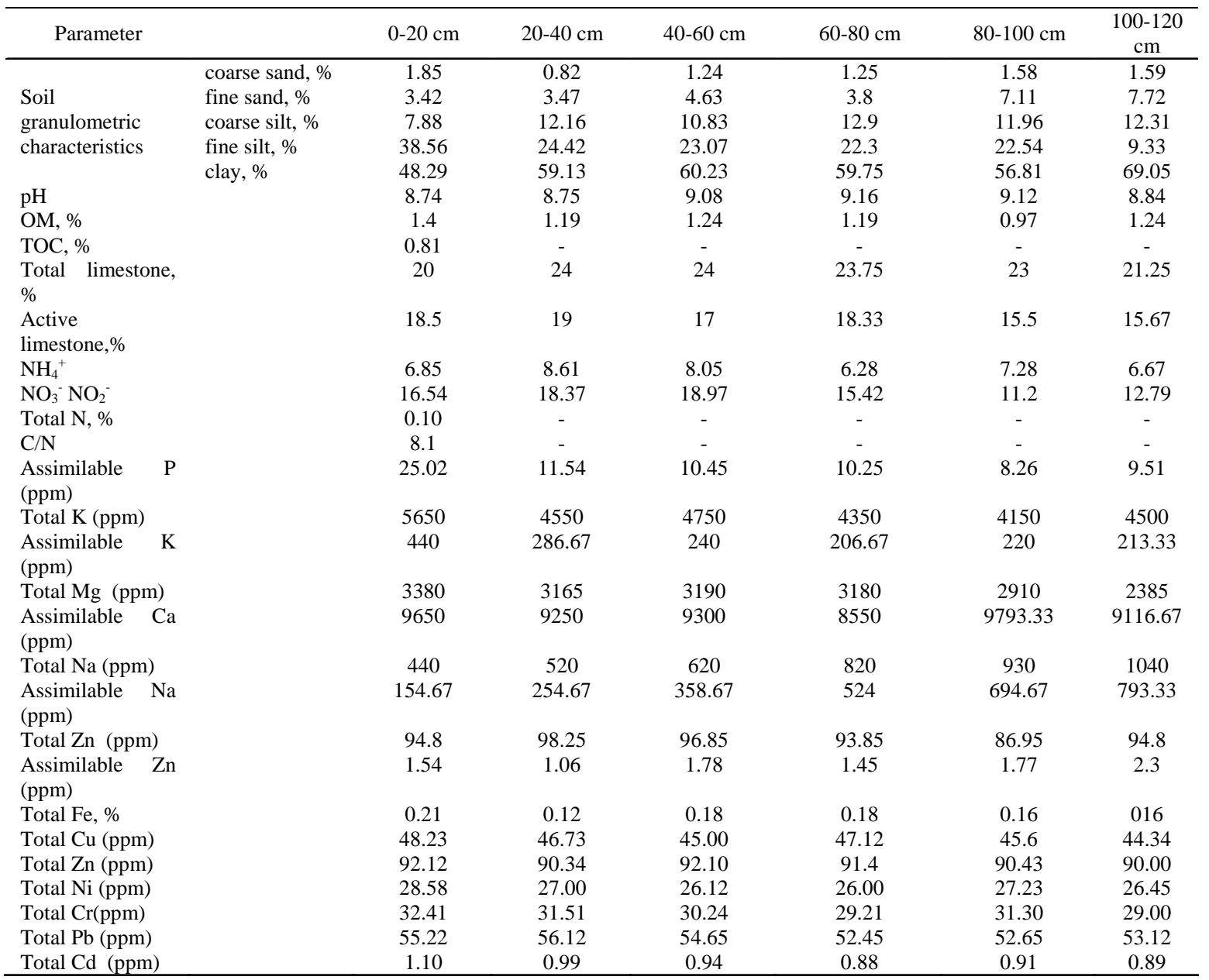


by regular temperature measurements inside the waste pile and $\mathrm{C} / \mathrm{N}$ ratio and decrease. Table 2 reports on some physico-chemical characteristics of the MSWC used in this study. Two levels of MSWC (40 and $80 \mathrm{t} / \mathrm{ha} / \mathrm{y}$ ) had been used yearly as autumnal amendment (1999-2000-2001-2002). Therefore, three soil treatments were named and distributed as follows:

T: Non-treated soil (control)

C1: MSWC added at $40 \mathrm{t} / \mathrm{ha} / \mathrm{y}$

C2: MSWC added at $80 \mathrm{t} / \mathrm{ha} / \mathrm{y}$

Table 2: Compost physico-chemical characteristics

\begin{tabular}{lr}
\hline Parameter & \\
\hline $\mathrm{pH}$ & 7.88 \\
$\mathrm{EC}(\mu \mathrm{s} / \mathrm{cm})$ & 933 \\
$\mathrm{C}, \%$ & 17.52 \\
$\mathrm{~N}, \%$ & 1.76 \\
$\mathrm{C} / \mathrm{N}$ & 9.78 \\
$\mathrm{Cd}(\mathrm{mg} / \mathrm{kg})$ & 5.17 \\
$\mathrm{~Pb}(\mathrm{mg} / \mathrm{kg})$ & 411.5 \\
$\mathrm{Cr}(\mathrm{mg} / \mathrm{kg})$ & 78.87 \\
$\mathrm{Ni}(\mathrm{mg} / \mathrm{kg})$ & 90.80 \\
$\mathrm{Cu}(\mathrm{mg} / \mathrm{kg})$ & 337 \\
$\mathrm{Zn}(\mathrm{mg} / \mathrm{kg})$ & 1174.5 \\
\hline
\end{tabular}

All soil treatments were in four replicates. Plots were yearly cropped with irrigated durum wheat "cultivar Karim" (cv Karim) after MSWC amendments. After harvest (late June), surface soil $(0-20 \mathrm{~cm})$ and plant samples were collected from each plot for subsequent analyses.

\section{Heavy metal analysis}

Total heavy metals in soil and different parts of wheat plants were extracted by mineralizing $1 \mathrm{~g}$ of dry weight sample in concentrated $\mathrm{HNO}_{3}-\mathrm{HCl}$ (1:3) for 12 $\mathrm{h}$ at ambient temperature, then for $8 \mathrm{~h}$ at $180^{\circ} \mathrm{C}$. Cd, $\mathrm{Cr}, \mathrm{Cu}, \mathrm{Ni}, \mathrm{Pb}$ and $\mathrm{Zn}$ concentrations were determined by AAS and their content expressed as mg per $\mathrm{g} \mathrm{dw}$ (Ayten, 2004).

\section{Statistical analysis}

Data were processed using STATISTICA 5.0 software and analyzed with ANOVA and F-test for mean separation.

\section{RESULTS AND DISCUSSION}

Table 3 reports on the variation of the total heavy metals content in top soil $(0-20 \mathrm{~cm})$ during 4 years of successive MSWC amendments.

At the end of the experimental period, $\mathrm{Cd}, \mathrm{Cr}, \mathrm{Ni}$, $\mathrm{Pb}, \mathrm{Cu}$ and $\mathrm{Zn}$ concentrations increased significantly in MSWC-amended soils as, compared to untreated control soils (Table 3). This increase was greater in soils amended with MSWC at the rate of $80 \mathrm{t} / \mathrm{ha}$.

Table 3: Variation of total heavy metal concentration $(\mathrm{mg} / \mathrm{kg})$ in different soil treatments $(0-20 \mathrm{~cm})$ during $4 \mathrm{consecutive} \mathrm{years}$

\begin{tabular}{|c|c|c|c|c|c|c|c|c|c|}
\hline \multirow[t]{2}{*}{ Year } & \multicolumn{2}{|c|}{$\mathrm{Cd}$} & \multicolumn{3}{|c|}{$\mathrm{Cr}$} & \multicolumn{4}{|c|}{$\mathrm{Ni}$} \\
\hline & $\mathrm{T}$ & $\mathrm{C} 1$ & $\mathrm{C} 2$ & $\mathrm{~T}$ & C1 & $\mathrm{C} 2$ & $\mathrm{~T}$ & C1 & $\mathrm{C} 2$ \\
\hline 1 & $1.05^{\mathrm{a}}$ & $1.06^{\mathrm{a}}$ & $1.06^{\mathrm{a}}$ & $34.21^{\mathrm{a}}$ & $36.64^{\mathrm{a}}$ & $40.06^{\mathrm{a}}$ & $29.90^{\mathrm{a}}$ & $30.54^{\mathrm{a}}$ & $32.80^{\mathrm{a}}$ \\
\hline 2 & $0.88^{\mathrm{a}}$ & $1.15^{\mathrm{a}}$ & $1.17^{\mathrm{a}}$ & $34.05^{\mathrm{a}}$ & $40.53^{a}$ & $41.70^{\mathrm{a}}$ & $25.74^{\mathrm{a}}$ & $28.63^{\mathrm{a}}$ & $31.29^{\mathrm{a}}$ \\
\hline 3 & $1.05^{\mathrm{a}}$ & $1.31^{\mathrm{a}}$ & $1.56^{\mathrm{b}}$ & $33.62^{a}$ & $41.85^{\mathrm{a}}$ & $49.95^{b}$ & $29.58^{\mathrm{a}}$ & $36.82^{b}$ & $43.94^{\mathrm{b}}$ \\
\hline 4 & $1.00^{\mathrm{a}}$ & $1.96^{\mathrm{b}}$ & $2.51^{b}$ & $35.02^{\mathrm{a}}$ & $52.96^{b}$ & $64.15^{b}$ & $29.26^{\mathrm{a}}$ & $40.89^{b}$ & $57.13^{c}$ \\
\hline \multirow[t]{2}{*}{ Year } & & $\mathrm{Pb}$ & & \multicolumn{3}{|c|}{$\mathrm{Cu}$} & \multicolumn{3}{|c|}{$\mathrm{Zn}$} \\
\hline & $\mathrm{T}$ & $\mathrm{C} 1$ & $\mathrm{C} 2$ & $\mathrm{~T}$ & $\mathrm{C} 1$ & $\mathrm{C} 2$ & $\mathrm{~T}$ & $\mathrm{C} 1$ & $\mathrm{C} 2$ \\
\hline 1 & $58.27^{\mathrm{a}}$ & $54.71^{\mathrm{a}}$ & $54.37^{\mathrm{a}}$ & $50.81^{\mathrm{a}}$ & $51.96^{\mathrm{a}}$ & $54.66^{\mathrm{a}}$ & $96.78^{\mathrm{a}}$ & $89.83^{\mathrm{a}}$ & $98.92^{\mathrm{a}}$ \\
\hline 2 & $50.53^{a}$ & $59.11^{\mathrm{a}}$ & $63.06^{\mathrm{ab}}$ & $48.67^{\mathrm{a}}$ & $54.95^{\mathrm{a}}$ & $57.10^{\mathrm{a}}$ & $88.78^{a}$ & $96.63^{\mathrm{b}}$ & $100.3^{\mathrm{a}}$ \\
\hline 3 & $57.02^{\mathrm{a}}$ & $70.97^{b}$ & $84.71^{\text {bc }}$ & $55.13^{\mathrm{a}}$ & $68.62^{b}$ & $81.90^{\mathrm{b}}$ & $98.88^{\mathrm{a}}$ & $123.1^{\mathrm{bc}}$ & $146.9^{b}$ \\
\hline 4 & $66.64^{a}$ & $105.2^{c}$ & $126.4^{\mathrm{c}}$ & $51.01^{\mathrm{a}}$ & $73.58^{b}$ & $89.37^{\mathrm{b}}$ & $92.31^{\mathrm{a}}$ & $151.4^{c}$ & $176.3^{c}$ \\
\hline
\end{tabular}

T: Control soil (unamended plots); C1: 40 t MSWC/ha/y; C2: 80 t MSWC/ha/y

Column values with different superscripts for each element indicate a significant difference at $P<0.05$ 
For instance, percent elevation for the six measured heavy metals after four amendments varied between $79 \%$ for $\mathrm{Cr}$ to $130 \%$ for $\mathrm{Cd}$ and $\mathrm{Pb}$ as compared to heavy metals content in the experimental soil. Repetitive addition of MSWC has been shown to inevitably increase heavy metals content in the surface layer of amended soils (Giusquiani et al., 1995; Crecchio et al., 2004; Madrid et al., 2006; Benzarti et al., 2007; Nwachukwu et al., 2010; Zaman, 2010). A parallel investigation on the same experimental but unplanted soils revealed that heavy metals and other potentially toxic elements content in soil greatly increased in the presence of MSWC after the second amendment (Yoshida et al., 2003; Benzarti et al., 2007). Table 4 illustrates heavy metals concentration in the whole wheat plants grown on MSWC-amended plots and controls. The mean whole wheat plant dry weight increased continuously and proportionally to MSWC dose in the treated plots as result of beneficial soil enrichment with nutrients (GallardoLara and Nogales, 1987; Hamdi et al., 2003, Castaldi et al., 2005). Both $\mathrm{Cd}$ and $\mathrm{Pb}$ were not detected in plant tissues throughout the whole period of investigation (lower than $100 \mathrm{ppb}$ for the analytical method used). As for MSWC-amended soils, measured heavy metals in plants were significantly greater than in control and were proportional to the level and number of MSWC amendments (Table 4). At the end of the experimental period, the content of heavy metals in plant tissues was the highest as compared to the previous sampling campaigns. This increase varied between 2 and 6-fold for $\mathrm{Zn}$ and $\mathrm{Cr}$, respectively. The accumulation of $\mathrm{Zn}$ was the least as this element is known to be a mobile metal, easily leached by water infiltration in soil (Ayari et al., 2008).

Total translocated $\mathrm{Cr}, \mathrm{Ni}, \mathrm{Cu}$ and $\mathrm{Zn}$ and their percent distribution in plant parts during the 4 years of MSWC amendment are presented in Tables 5-8. Absorbed heavy metals by wheat plants in the treated plots remained greater than those in untreated plots. For instance, $\mathrm{Cr}, \mathrm{Ni}$ and $\mathrm{Cu}$ in plant tissues from plots treated with $80 \mathrm{t}$ MSWC/ha/y were about 3-fold higher than in plants grown on soil amended at the rate of $40 \mathrm{t}$ MSWC/ha/y. With a few exceptions, the general mean distribution of heavy metals in different plant parts was constant and was the same for plants grown with or without MSWC (Tables 5-8).

$\mathrm{Cu}$ and $\mathrm{Zn}$, which are common micronutrients for the plants, were found in all plant parts including grains (Tables 7 and 8). The quantity absorbed by the plants from treated plots was higher, though their distribution was uniform in all plants from all treatments. Among the phytotoxic heavy metals studied in this research work ( $\mathrm{Ni}, \mathrm{Cr}$ and $\mathrm{Pb}$ ), Ni was the most mobile (Kabata-Pendias and Pendias, 1992) although it was not detected in the grains (Hamdi et al., 2003). On the other hand, toxic Cr was less mobile and accumulated mainly in root tissues (more than $70 \%)$.

Although heavy metals concentration in MSWCamended soils generally increased during the experimental period (Table 3), the total concentration of detected metals per plant tended to be stagnant from the second year of treatment because plant weight was enhanced by the fertilizing effect of the compost (Tables 5-8). The values obtained for heavy metals concentrations in the whole plant did not exceed the critical concentrations for plant growth and animal feed reported by Förstner (1995). Considering that the average weight distribution of stalks+leaves and grains were $41.8 \%( \pm 1,5)$ and $48.2 \%( \pm 1,3)$, respectively, the average concentrations of heavy metals in analyzed plant parts varied from 1.7 to $12.9 \mathrm{mg} / \mathrm{kg}$ for $\mathrm{Cr}, 2.1$ to 14 $\mathrm{mg} / \mathrm{kg}$ for $\mathrm{Ni}, 7.2$ to $26.6 \mathrm{mg} / \mathrm{kg}$ for $\mathrm{Cu}$ and 66.8 to $118.7 \mathrm{mg} / \mathrm{kg}$ for $\mathrm{Zn}$. These values are all below the lower limit of critical concentrations for animal feed. It can therefore be concluded that the long-term application of large amounts of urban waste compost to soils with similar physico-chemical characteristics does not necessarily cause medium-term problems to plant, animal and human health.

The plant/soil transfer coefficients (Kloke et al., 1984) are shown in Table 9. Transfer coefficient (TC) is obtained from the ratio of each detected metal concentration in fresh plant tissues to that in soil. The TC quantifies the relative differences in bioavailability of soil metal to plant and is a function of both soil and plant properties. Control soils showed TC below the range of threshold values reported in literature (Förstner, 1995), testifying to the absence of heavy metals accumulation risks within plant tissues. In presence of MSWC, TC of $\mathrm{Cr}$, $\mathrm{Ni}$ and $\mathrm{Cu}$ were higher than standard values counting from the second year of the biowaste amendment, indicating that there was an important load/transfer of metal ions from amended soils to wheat plants. TC values were always positively 
Table 4. Variation of whole plant dry weight and plant content in heavy metal during 4 consecutive years

\begin{tabular}{|c|c|c|c|c|c|c|c|c|c|}
\hline & & & & \multicolumn{6}{|c|}{ Heavy metals (mg/kg) } \\
\hline & & & & \multicolumn{3}{|c|}{$\mathrm{Cr}$} & \multicolumn{3}{|c|}{$\mathrm{Ni}$} \\
\hline & & & & $\mathrm{T}$ & C1 & C2 & $\mathrm{T}$ & C1 & C2 \\
\hline & & & & $0.39^{\mathrm{a}}$ & $1.00^{\mathrm{a}}$ & $2.87^{\mathrm{a}}$ & $0.23^{\mathrm{a}}$ & $1.16^{\mathrm{a}}$ & $3.04^{\mathrm{a}}$ \\
\hline & & & & $0.66^{\mathrm{a}}$ & $4.61^{\mathrm{b}}$ & $10.87^{\mathrm{b}}$ & $0.66^{\mathrm{a}}$ & $4.41^{\mathrm{b}}$ & $10.34^{\mathrm{b}}$ \\
\hline \multirow[t]{2}{*}{ Year } & \multicolumn{3}{|c|}{ Dry wt. (mg) } & $0.63^{\mathrm{a}}$ & $5.39^{\mathrm{b}}$ & $12.10^{\mathrm{b}}$ & $0.68^{\mathrm{a}}$ & $5.63^{\mathrm{b}}$ & $12.46^{\mathrm{b}}$ \\
\hline & $\mathrm{T}$ & $\mathrm{C} 1$ & $\mathrm{C} 2$ & $0.60^{\mathrm{a}}$ & $5.95^{\mathrm{b}}$ & $13.35^{\mathrm{b}}$ & $0.67^{\mathrm{a}}$ & $6.20^{\mathrm{b}}$ & $13.70^{\mathrm{b}}$ \\
\hline 1 & $90.5^{\mathrm{a}}$ & $110.2^{\mathrm{a}}$ & $130.3^{\mathrm{a}}$ & & & & & & \\
\hline 2 & $120.3^{\mathrm{a}}$ & $150.5^{\mathrm{ab}}$ & $200.6^{\mathrm{b}}$ & & $\mathrm{Cu}$ & & & $\mathrm{Zn}$ & \\
\hline 3 & $100.2^{\mathrm{a}}$ & $198.4^{\mathrm{b}}$ & $250.4^{\mathrm{b}}$ & $\mathrm{T}$ & C1 & $\mathrm{C} 2$ & $\mathrm{~T}$ & $\mathrm{C} 1$ & $\mathrm{C} 2$ \\
\hline \multirow[t]{4}{*}{4} & $96.5^{\mathrm{a}}$ & $211.0^{\mathrm{b}}$ & $253.2^{\mathrm{b}}$ & $1.83^{\mathrm{a}}$ & $4.18^{\mathrm{a}}$ & $7.12^{\mathrm{a}}$ & $19.77^{\mathrm{a}}$ & $36.78^{\mathrm{a}}$ & $53.34^{\mathrm{a}}$ \\
\hline & & & & $1.77^{\mathrm{a}}$ & $11.51^{b}$ & $25.26^{\mathrm{b}}$ & $18.43^{\mathrm{a}}$ & $51.38^{\mathrm{b}}$ & $71.65^{\mathrm{b}}$ \\
\hline & & & & $1.68^{\mathrm{a}}$ & $15.32^{\mathrm{b}}$ & $33.34^{\mathrm{b}}$ & $18.41^{\mathrm{a}}$ & $62.75^{\mathrm{b}}$ & $77.05^{\mathrm{b}}$ \\
\hline & & & & $1.75^{\mathrm{a}}$ & $16.89^{\mathrm{b}}$ & $36.72^{\mathrm{b}}$ & $18.36^{\mathrm{a}}$ & $66.78^{\mathrm{b}}$ & $82.05^{\mathrm{b}}$ \\
\hline
\end{tabular}

T: Control soil (unamended plots); C1: 40 t MSWC/ha/y; C2: 80 t MSWC/ha/y

Column values with different superscripts for each element indicate a significant difference at $P<0.05$

Table 5: Chromium content and distribution in different plant parts during 4 consecutive years

\begin{tabular}{|c|c|c|c|c|c|c|c|c|c|c|c|c|}
\hline \multirow{3}{*}{ Year } & \multirow{2}{*}{\multicolumn{3}{|c|}{ Total Cr (mg/plant) }} & \multicolumn{9}{|c|}{ Distribution in plant parts (\%) } \\
\hline & & & & \multicolumn{3}{|c|}{ roots } & \multicolumn{3}{|c|}{ (stalks + leaves) } & \multicolumn{3}{|c|}{ grains } \\
\hline & $\mathrm{T}$ & C1 & $\mathrm{C} 2$ & $\mathrm{~T}$ & $\mathrm{C} 1$ & $\mathrm{C} 2$ & $\mathrm{~T}$ & $\mathrm{C} 1$ & $\mathrm{C} 2$ & $\mathrm{~T}$ & C1 & $\mathrm{C} 2$ \\
\hline 1 & 0.04 & 0.11 & 0.37 & 86.51 & 65.78 & 80.56 & 13.49 & 34.22 & 19.44 & ND & ND & ND \\
\hline 2 & 0.08 & 0.69 & 2.18 & 64.11 & 66.51 & 66.51 & 35.89 & 33.49 & 33.49 & ND & ND & ND \\
\hline 3 & 0.06 & 1.07 & 3.03 & 63.62 & 65.11 & 67.91 & 36.38 & 34.89 & 32.09 & ND & ND & ND \\
\hline 4 & 0.06 & 1.26 & 3.38 & 61.80 & 64.82 & 67.79 & 38.20 & 35.18 & 32.21 & ND & ND & ND \\
\hline Average & 0.06 & 0.78 & 2.24 & 69.01 & 65.55 & 70.69 & 30.99 & 34.44 & 29.30 & ND & $\mathrm{ND}$ & ND \\
\hline
\end{tabular}

T: Control soil (unamended plots); C1: 40 t MSWC/ha/y; C2: 80 t MSWC/ha/y

ND: Not detected

Table 6: Nickel content and distribution in different plant parts during 4 consecutive years

\begin{tabular}{|c|c|c|c|c|c|c|c|c|c|c|c|c|}
\hline \multirow{3}{*}{ Year } & \multirow{2}{*}{\multicolumn{3}{|c|}{ Total Ni (mg/plant) }} & \multicolumn{6}{|c|}{ Distribution in plant parts (\%) } & & & \\
\hline & & & & \multicolumn{3}{|c|}{ roots } & \multicolumn{3}{|c|}{ (stalks + leaves) } & \multicolumn{3}{|c|}{ grains } \\
\hline & $\mathrm{T}$ & C1 & $\mathrm{C} 2$ & $\mathrm{~T}$ & C1 & $\mathrm{C} 2$ & $\mathrm{~T}$ & C1 & $\mathrm{C} 2$ & $\mathrm{~T}$ & $\mathrm{C} 1$ & $\mathrm{C} 2$ \\
\hline 1 & 0.02 & 0.13 & 0.40 & 72.00 & 70.33 & 77.06 & 28.00 & 29.67 & 22.94 & ND & $\mathrm{ND}$ & ND \\
\hline 2 & 0.08 & 0.66 & 2.07 & 60.05 & 65.11 & 65.44 & 39.95 & 34.89 & 34.56 & ND & $\mathrm{ND}$ & ND \\
\hline 3 & 0.07 & 1.12 & 3.12 & 54.57 & 61.69 & 65.92 & 45.43 & 38.31 & 34.08 & ND & $\mathrm{ND}$ & ND \\
\hline 4 & 0.06 & 1.31 & 3.47 & 51.75 & 61.61 & 66.01 & 48.25 & 38.39 & 33.99 & ND & $\mathrm{ND}$ & ND \\
\hline Average & 0.06 & 0.80 & 2.26 & 59.59 & 64.68 & 68.60 & 40.41 & 35.32 & 31.40 & ND & $\mathrm{ND}$ & ND \\
\hline
\end{tabular}

T: Control soil (unamended plots); C1: 40 t MSWC/ha/y; C2: 80 t MSWC/ha/y

ND: Not detected 
F. Ayari et al.

Table 7: Copper content and distribution in different plant parts during 4 consecutive years

\begin{tabular}{|c|c|c|c|c|c|c|c|c|c|c|c|c|}
\hline \multirow{3}{*}{ Year } & \multirow{2}{*}{\multicolumn{3}{|c|}{ Total Cu (mg/plant) }} & \multicolumn{8}{|c|}{ Distribution in plant parts (\%) } & \\
\hline & & & & \multicolumn{3}{|c|}{ roots } & \multicolumn{3}{|c|}{ (stalks + leaves) } & \multicolumn{3}{|c|}{ grains } \\
\hline & $\mathrm{T}$ & $\mathrm{C} 1$ & $\mathrm{C} 2$ & $\mathrm{~T}$ & $\mathrm{C} 1$ & $\mathrm{C} 2$ & $\mathrm{~T}$ & $\mathrm{C} 1$ & $\mathrm{C} 2$ & $\mathrm{~T}$ & $\mathrm{C} 1$ & $\mathrm{C} 2$ \\
\hline 1 & 0.17 & 0.46 & 0.93 & 26.98 & 42.85 & 50.78 & 43.50 & 39.04 & 26.44 & 29.53 & 18.11 & 22.78 \\
\hline 2 & 0.21 & 1.73 & 5.07 & 33.92 & 41.78 & 44.92 & 31.47 & 35.61 & 37.89 & 34.61 & 22.60 & 17.20 \\
\hline 3 & 0.17 & 3.04 & 8.35 & 38.42 & 47.70 & 51.72 & 32.57 & 31.34 & 31.55 & 29.01 & 20.96 & 16.73 \\
\hline 4 & 0.17 & 3.56 & 9.30 & 38.23 & 47.53 & 51.71 & 32.74 & 31.59 & 31.69 & 29.03 & 20.88 & 16.60 \\
\hline Average & 0.18 & 2.20 & 5.91 & 34.38 & 44.96 & 49.78 & 35.07 & 34.39 & 31.89 & 30.54 & 20.63 & 18.32 \\
\hline
\end{tabular}

T: Control soil (unamended plots); C1: 40 t MSWC/ha/y; C2: 80 t MSWC/ha/y

Table 8: Zinc content and distribution in different plant parts during 4 consecutive years

\begin{tabular}{|c|c|c|c|c|c|c|c|c|c|c|c|c|}
\hline \multirow{3}{*}{ Year } & \multirow{2}{*}{\multicolumn{3}{|c|}{ Total Zn (mg/plant) }} & \multicolumn{9}{|c|}{ Distribution in plant parts (\%) } \\
\hline & & & & \multicolumn{3}{|c|}{ roots } & \multicolumn{3}{|c|}{ (stalks + leaves) } & \multicolumn{3}{|c|}{ grains } \\
\hline & $\mathrm{T}$ & $\mathrm{C} 1$ & C2 & $\mathrm{T}$ & C1 & C2 & $\mathrm{T}$ & $\mathrm{C} 1$ & C2 & $\mathrm{T}$ & $\mathrm{C} 1$ & $\mathrm{C} 2$ \\
\hline 1 & 1.79 & 4.05 & 6.95 & 33.47 & 39.52 & 45.63 & 21.39 & 23.08 & 27.95 & 45.14 & 37.40 & 26.42 \\
\hline 2 & 2.22 & 7.73 & 14.37 & 27.41 & 36.52 & 38.66 & 21.74 & 28.85 & 30.63 & 50.85 & 34.64 & 30.71 \\
\hline 3 & 1.84 & 12.45 & 19.29 & 29.13 & 41.35 & 37.08 & 22.66 & 26.51 & 32.63 & 48.22 & 32.13 & 30.29 \\
\hline 4 & 1.77 & 14.09 & 20.78 & 29.82 & 40.75 & 36.61 & 23.50 & 26.99 & 33.13 & 46.68 & 32.26 & 30.26 \\
\hline Average & 1.91 & 9.58 & 15.35 & 29.96 & 39.54 & 39.50 & 22.32 & 26.36 & 31.09 & 47.72 & 34.11 & 29.42 \\
\hline
\end{tabular}

T: Control soil (unamended plots); C1: 40 t MSWC/ha/y; C2: 80 t MSWC/ha/y

Table 9: Plant/soil transfer coefficients for absorbed metals during 4 consecutive years

\begin{tabular}{|c|c|c|c|c|c|c|c|c|c|c|c|c|}
\hline \multirow[t]{2}{*}{ Year } & \multicolumn{3}{|c|}{$\mathrm{Cr}$} & \multicolumn{3}{|c|}{$\mathrm{Ni}$} & \multicolumn{3}{|c|}{$\mathrm{Cu}$} & \multicolumn{3}{|c|}{$\mathrm{Zn}$} \\
\hline & $\mathrm{T}$ & C1 & $\mathrm{C} 2$ & $\mathrm{~T}$ & C1 & $\mathrm{C} 2$ & $\mathrm{~T}$ & C1 & $\mathrm{C} 2$ & $\mathrm{~T}$ & C1 & $\mathrm{C} 2$ \\
\hline 1 & 0.01 & 0.03 & 0.07 & 0.01 & 0.04 & 0.09 & 0.04 & 0.08 & 0.13 & 0.20 & 0.41 & 0.54 \\
\hline 2 & 0.02 & 0.11 & 0.26 & 0.03 & 0.15 & 0.33 & 0.04 & 0.21 & 0.44 & 0.21 & 0.53 & 0.71 \\
\hline 3 & 0.02 & 0.13 & 0.24 & 0.02 & 0.15 & 0.28 & 0.03 & 0.22 & 0.41 & 0.19 & 0.51 & 0.52 \\
\hline 4 & 0.02 & 0.11 & 0.21 & 0.02 & 0.15 & 0.24 & 0.03 & 0.23 & 0.41 & 0.20 & 0.44 & 0.47 \\
\hline Range & \multicolumn{3}{|c|}{$0.01-0.1$} & \multicolumn{3}{|c|}{$0.01-0.1$} & \multicolumn{3}{|c|}{$0.01-0.1$} & \multicolumn{3}{|c|}{$1-10$} \\
\hline
\end{tabular}

T: Control soil (unamended plots); C1: 40 t MSWC/ha/y; C2: 80 t MSWC/ha/y

proportional to the level of MSWC in soil for 4 consecutive years with the following order: C2 > C1 $>\mathrm{T}$ (Table 9). On the other hand, plant/soil TCs in MSWC-amended plots significantly increased after the second amendment before stabilization in the case of $\mathrm{Ni}$ and $\mathrm{Cu}$ or even a decrease in the case of Zn (Table 9).

\section{CONCLUSION}

Trace metal composition of MSWC-amended soil is an important factor to estimate total trace metal uptake by plants and consequently the level of risk of these elements for plants and food chain. In this study, heavy metals accumulation in the top $20 \mathrm{~cm}$ of a Tunisian clayey loam soil amended with MSWC for four consecutive years at the rate of 40 or $80 \mathrm{t} /$ ha/y was evaluated. By time, the content of measured heavy metals significantly increased in the MSWC amended plots. Wheat plants grown on MSWCamended soils showed also a general increase in metal 
uptake and translocation. However, only $\mathrm{Zn}$ and $\mathrm{Cu}$ were detected in the edible parts for humans (grains). On the other hand, $\mathrm{Cr}$ and $\mathrm{Ni}$ were less mobile and were accumulated essentially in root tissues. Transfer coefficients increased with the level of MSWC in soil for 4 years reflecting the important load/transfer of heavy metals in the soil/plant system.

\section{ACKNOWLEDGEMENTS}

This study was funded (Grant No. CP-99) by the Tunisian Secretariat for Scientific Research and Technology. The authors would like to thank Hanen Dhaouadi, Kais Bouthouri and Mohamed Bouthouri for their technical assistance.

\section{REFERENCES}

Ayari, F.; Chairi, R.; Kossai, R., (2008). Sequential extraction of heavy metals during composting of urban waste. Chin. J. Geochem., 27, 121-125 (6 pages).

Ayten, K., (2004). Effect of organic wastes on the extractability of cadmium, copper, nickel, and zinc in soil. Geoderma, 122, 297-303 (8 pages)

Benzarti, S.; Hamdi, H.; Aoyama, A.; Jedidi, N.; Hassen, A.; Dahmane, A., (2007). Assessment of the effect of repetitive municipal solid waste compost application on soil using physico-chemical analyses, solid-phase bioassays and microbial activity characterization. Jpn. J. Environ. Toxicol., 10 (1), 19-30 (12 pages).

Castaldi, P.; Santoma, L.; Melis, P., (2005). Heavy metal immobilization by chemical amendments in a polluted soil and influence on white lupin growth. Chemosphere, 60 (3), 365-371 (7 pages).

Chukwujindu, M. A. I.; Egun, A. C.; Emuh, F. N.; Isirimah, N. O., (2006). Compost maturity evaluation and its significance to agriculture. Pak. J. Biol. Sci., 9 (15), 125131 ( 7 pages).

Chukwuji M. A. I.; Nwajei, G. E.; Osakwe, S. A., (2005). Recycling waste in agriculture: Efficacy of composting in ameliorating trace metal availability and soil borne pathogens. Eur. J. Sci. Res., 11 (4), 571-577 (7 pages).

Crecchio, C.; Curci, M.; Pizzigallo, M. D. R.; Ricciuti, P.; Ruggiero, P., (2004). Effect of municipal solid waste compost amendments on soil enzymes activities and bacterial genetic diversity. Soil Bio. Biochem., 36 (10), 1595-1605 (12 pages).

European Community (1975). Commission Directive No. 442. Off. J. Eur. Commun., 194, 47-49 (3 pages).

European Community (1986). Commission Directive No. 278. Off. J. Eur. Commun., 181, 5-12 (8 pages).

Förstner, U., (1995). Land contamination by metals: global scope and magnitude of problem. Alien, H. E.; Huang, C. P.; Bailey, G. W.; Bowers, A. R. (Eds). Metal speciation and contamination of soil. Lewis, Boca Raton. 1-33.

Gallardo-Lara, F.; Nogales, R., (1987). Effect of the application of town-refuse compost on the soil plant system: A review. Biol. Waste, 19 (1), 35-62 (28 pages).
Giusquiani, P. L.; Pagliai, M.; Gigliotti, G.; Businelli, D.; Benetti, A., (1995). Urban waste compost: Effects on physical, chemical and biochemical soil properties. J. Environ. Qual., 24, 175-182 (28 pages).

Hamdi, H.; Jedidi, N.; Ayari, F.; Yoshida, M.; Ghrabi, A., (2003). Valuation of municipal solid waste compost of Tunis (Tunisia) - Agronomic aspect. Proceedings of the 14th Annual Conference of the Japan Society of Waste Management Experts, Vol. III, International Session. 6264.

He, X. T.; Traina, S. J.; Logan, T. J., (1992). Chemical properties of municipal solid waste compost. J. Environ. Qual., 21, 318-329 (12 pages).

Kabata-Pendias, A.; Pendias, H., (1992). Trace elements in

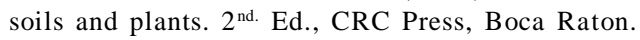

Kloke, A.; Sauerbeck, D. R.; Vetter, H., (1984). The contamination of plants and soils with heavy metals and the transport of metals in terrestrial food chains. Nriagu, J. O. (Ed.). Changing Metal Cycles and Human Health. Springer-Verlag, Berlin.

Kurihara, K., (1984). Urban and industrial waste as fertilizer material. Swaminathan, M. S. (Ed.). Organic matter and Rice. International Rice Research Institute Philippines.

Lillenberg, M.; Yurchenko, S.; Kipper, K.; Herodes, K.; Pihl, V.; Lõhmus, R.; Ivask, M.; Kuu, A.; Kutti, S.; Litvin, S. V.; Nei, L., (2010). Presence of fluoroquinolones and sulfonamides in urban sewage sludge and their degradation as a result of composting. Int. J. Environ. Sci. Tech., 7 (2), 307-312 (6 pages).

Madrid, F.; Lopez, R.; Cabrera, F., (2006). Metal accumulation in soil after application of municipal solid waste compost under intensive farming conditions. Agr. Ecosyst. Environ. 199 (3-4), 249-256 (8 pages).

Mahvi, A. H., (2008). Application of agricultural fibers in pollution removal from aqueous solution. Int. J. Environ. Sci. Tech., 5 (2), 275-285 (11 pages).

Mullin, G. L.; Mitchell, C. C., (1994). Soil amendments: Impact on biotic system. CRC Press Inc., New York.

Nicholson, F. A., Smith, S. R., Alloway, B. J., Carlton-Smith, C., Chambers, B. J., (2003). An inventory of heavy metals inputs to agricultural soils in England and Wales. Sci. Total Environ., 311 (1-3), 205-219 (15 pages).

Nouri, J.; Mahvi, A. H.; Babaei, A.; Ahmadpour, E., (2006). Regional pattern distribution of groundwater fluoride in the Shush aquifer of Khuzestan County Iran. Fluoride, 39 (4), 321-325 (5 pages).

Nouri, J.; Mahvi, A.H.; Jahed, G.R.; Babaei, A.A. (2008). Regional distribution pattern of groundwater heavy metals resulting from agricultural activities. Environ. Geo. 55 (6), 1337-1343 (7 pages).

Nwachukwu, M. A.; Feng, H.; Alinnor, J., (2010). Assessment of heavy metal pollution in soil and their implications within and around mechanic villages. Int. J. Environ. Sci. Tech., 7 (2), 347-358 (12 pages).

Paglia, M.; Vittori-Antisari, L., (1993). Influence of waste organic matter on soil micro and macrostructure. Bioresour. Tech., 43 (3), 205-213 (8 pages).

Petruzzelli, G.; Lubrano, L.; Guidi, G., (1989). Uptake by corn and chemical extractability of heavy metals from a four year compost treated soil. Plant Soil, 116 (1), 2327 (5 pages). 
Williams, D. E.; Vlarnis, J.; Pukite, A. H.; Corey, J. E. (1987). Metal movement in sludge-amended soils: A nine-year study. Soil Sci., 143, 124-131 (8 pages).

Yoshida, M.; Jedidi, N.; Hamdi, H.; Ayari, F.; Hassen, A.; M’hiri, A., (2003). Magnetic susceptibility variation of MSW compost-amended soils: In situ method for monitoring heavy metal contamination. Waste Manage. Res., 21 (2), 155160 (6 pages).

Zaman, A. U., (2010). Comparative study of municipal solid waste treatment technologies using life cycle assessment method. Int. J. Environ. Sci. Tech., 7 (2), 225-234 (10 pages).

\section{AUTHOR (S) BIOSKETCHES}

$\$ \backslash$ DUा

Email: fethia_ayari@yahoo.fr

Hamdi, H., Ph.D., Water Research and Technology Center, Borj Cédria Technopark, P.O. Box 273 Soliman 8020, Tunisia. Email: helmi.hamdi@certe.rnrt.tn

Jedidi, N., Ph.D., Water Research and Technology Center, Borj Cédria Technopark, P.O. Box 273 Soliman 8020, Tunisia. Email: naceur.jedidi@certe.rnrt.tn

Gharbi, N., Ph.D., University of Tunis. Rue Jawaher Lel Nehru, Montfleury 1008, Tunis, Tunisia.

Email: gharbi_neji@yahoo.fr

Kossai, R., Ph.D., University of Tunis. Rue Jawaher Lel Nehru, Montfleury 1008, Tunis, Tunisia. Email: ridha_kossai@topnet.tn 